\title{
KEBIJAKAN PEMEKARAN WILAYAH DAN PENGEMBANGAN PUSAT PERTUMBUHAN EKONOMI KOTA TASIKMALAYA
}

\author{
(Regional Autonomy Policy and \\ the Development of Central of Economic Growth of Tasikmalaya City)
}

\author{
Ebed Hamri", Eka Intan Kumala Putri* ${ }^{* *}$ Hermanto J. Siregar ${ }^{* *}$, dan Deddy S. Bratakusumah ${ }^{* * *}$ \\ *Badan Perencanaan Pembangunan Daerah Kab. Konawe, Provinsi Sulawesi Tenggara \\ Jl. Inolobunggadue No. 2, Kel. Puunaaha, Kec. Unaaha Kab. Konawe, E-mail: *nickebhamri@yahoo.co.id \\ **Fakultas Ekonomi dan Manajemen, Institut Pertanian Bogor, Jl. Raya Dramaga, Dramaga, Bogor, \\ Email: ekaintanputri@yahoo.com dan hermansiregar@yahoo.com \\ ***Pusbindiklatren, Jl. Proklamasi No. 70, Jakarta Pusat, Email: deddys@bappenas.go.id
}

Naskah diterima: 11 Mei 2015

Naskah direvisi: 25 Mei 2015

Naskah diterbitkan: 30 Juni 2016

\begin{abstract}
The research was conducted at Tasikmalaya City as a city resulted from regional autonomy in 2001 and had developed into a center of economic development in Priangan Timur area of West Java Province. The research was aimed to analyze the development of regional economic structure and superior sector which was the economic competitiveness of Tasikmlaya City compare to other surrounding areas. The research was used analysis of Klassen typology, Entropy Diversity Index (EDI) analysis, and Location Quotient (LQ) analysis. The research indicated a result analysis of Klassen typology that Tasikmalaya City was within the classification of fast growth area; whereas, hinterland regencies were within the classification of relatively remote area. The result of EDI analysis shows that the average entropy index of Tasikmalaya City (0.85) was bigger than the average entropy value of its hinterlands, which were Tasikmalaya Regency (0.71), Garut Regency (0.67), Ciamis Regency (0.81), Banjar City (0.83), and Pangandaran Regency (0,74). The higher value of entropy shows that regional economic of Tasikmalaya City was more advanced and developed. LQ analysis indicated that the average LQ of Tasikmalaya City was higher than hinterland area. The result shows average LQ value of Tasikmalaya City (12.80) was bigger than the average LQ value of its hinterland; which were Tasikmalaya Regency (9.73), Garut Regency (9.25), Ciamis Regency (11.23), Banjar City (10.91), and Pangandaran Regency (10.20). The superior sectors that became the economic basis sector of Tasikmalaya City were building, trade, hotel and restaurant, transportation and communication, finance, rent and financial services, and services. Keywords: regional autonomy, Klassen typology, entropy diversity, location quotient, growth center
\end{abstract}

\begin{abstract}
Abstrak
Penelitian ini dilakukan di Kota Tasikmalaya sebagai kota hasil pemekaran tahun 2001 dan berkembang sebagai pusat pertumbuhan ekonomi di wilayah Priangan Timur Provinsi Jawa Barat. Penelitian bertujuan menganalisis perkembangan struktur perekonomian wilayah dan sektor unggulan yang menjadi daya saing perekonomian wilayah Kota Tasikmalaya dibandingkan daerah sekitarnya (hinterland). Penelitian menggunakan analisis tipologi Klassen, Indeks Diversitas Entropi (IDE), dan Location Quotient (LQ). Penelitian menunjukkan bahwa berdasarkan hasil analisis tipologi Klassen, Kota Tasikmalaya termasuk klasifikasi daerah berkembang cepat, dibandingkan wilayah hinterland-nya Kabupaten Tasikmalaya, Kabupaten Garut, Kabupaten Ciamis, Kota Banjar, dan Kabupaten Pangandaran, masuk dalam klasifikasi daerah relatif tertinggal. Analisis IDE menunjukkan sektor-sektor perekonomian Kota Tasikmalaya lebih berkembang dibandingkan daerah hinterland-nya. Terlihat rata-rata indeks diversitas entropi Kota Tasikmalaya $(0,85)$ lebih besar dibandingkan rata-rata nilai entropi wilayah sekitarnya (hinterland), yaitu Kabupaten Tasikmalaya $(0,71)$, Kabupaten Garut $(0,67)$, Kabupaten Ciamis $(0,81)$, Kota Banjar $(0,83)$, dan Kabupaten Pangandaran $(0,74)$. Besarnya nilai entropi menunjukkan perekonomian wilayah Kota Tasikmalaya lebih maju dan berkembang. Sedangkan dari hasil analisis LQ menunjukkan rata-rata LQ Kota Tasikmalaya $(12,80)$ lebih besar dibandingkan rata-rata LQ wilayah hinterland-nya, yaitu Kabupaten Tasikmalaya $(9,73)$, Kabupaten Garut $(9,25)$, Kabupaten Ciamis $(11,23)$, Kota Banjar $(10,91)$, dan Kabupaten Pangandaran $(10,20)$. Sektor-sektor unggulan yang menjadi sektor basis ekonomi Kota Tasikmalaya adalah bangunan, perdagangan, hotel dan restoran, pengangkutan dan komunikasi, keuangan, persewaan dan jasa keuangan, serta jasa-jasa.

Kata kunci: pemekaran wilayah, tipologi Klassen, indeks diversitas entropi, kuosien lokasi, pusat pertumbuhan
\end{abstract}

\section{PENDAHULUAN}

\section{A. Latar Belakang}

Berlakunya Undang-Undang No. 22 Tahun 1999 yang telah direvisi dengan Undang-Undang No. 32 Tahun 2004 tentang Pemerintahan Daerah dengan titik sentral desentralisasi dan otonomi daerah, memberikan peluang bagi daerah-daerah untuk melakukan pemekaran wilayah. Realitas struktur pemerintahan terpusat (sentralisasi), kesenjangan wilayah (regional disparity), ketidakadilan, dan ketimpangan dalam hal pemerataan pembangunan (regional inequality), di satu sisi terjadi percepatan pembangunan dan penumpukan manufaktur, di sisi lain pembangunan berjalan sangat lambat mendorong kuatnya arus tuntutan daerah-daerah untuk melakukan pemekaran wilayah (Booth, 2011; Kuncoro, 2002). 
Tabel 1. Perkembangan Jumlah Daerah Otonom Baru Hasil Pemekaran di Indonesia Tahun 1999-2013

\begin{tabular}{|c|c|c|c|c|c|}
\hline Tahun & Provinsi & Kabupaten & Kota & Jumlah & Keterangan \\
\hline Sebelum 1999 & 26 & 234 & 59 & 319 & \multirow{2}{*}{$\begin{array}{l}\text { Masih mengacu pada UU No. } 5 \text { Tahun } 1974 \\
\text { tentang Pokok-Pokok Pemerintahan di } \\
\text { Daerah. }\end{array}$} \\
\hline 1999 & 2 & 34 & 9 & 45 & \\
\hline 2000 & 3 & - & - & 3 & $\begin{array}{l}\text { Mengacu UU No. } 22 \text { Tahun } 1999 \text { tetapi } \\
\text { belum berdasarkan PP No. } 129 \text { Tahun } 2000 .\end{array}$ \\
\hline 2001 & - & - & 12 & 12 & \multirow{4}{*}{$\begin{array}{l}\text { Mengacu UU No. } 22 \text { Tahun } 1999 \text { dan PP } \\
\text { No. } 129 \text { Tahun } 2000 \text { tentang Persyaratan } \\
\text { Pembentukan dan Kriteria Pemekaran, } \\
\text { Penghapusan dan Penggabungan Daerah. }\end{array}$} \\
\hline 2002 & 1 & 33 & 4 & 38 & \\
\hline 2003 & - & 47 & 2 & 49 & \\
\hline 2004 & 1 & - & - & 1 & \\
\hline 2007 & - & 21 & 4 & 25 & Berdasarkan PP No. 129 Tahun 2000. \\
\hline 2008 & - & 27 & 3 & 30 & \multirow{4}{*}{$\begin{array}{l}\text { Sejak November } 2008 \text { pemekaran wilayah } \\
\text { sudah berdasarkan PP No. } 78 \text { Tahun } \\
2007 \text { tentang Tata Cara Pembentukan, } \\
\text { Penghapusan dan Penggabungan Daerah. }\end{array}$} \\
\hline 2009 & - & 2 & - & 2 & \\
\hline 2012 & 1 & 4 & - & 5 & \\
\hline 2013 & - & 7 & - & 7 & \\
\hline $\begin{array}{l}\text { DOHP pasca UU No. } 22 \\
\text { Tahun } 1999\end{array}$ & 8 & 175 & 34 & 217 & \\
\hline $\begin{array}{l}\text { Total provinsi, kab/kota s.d. } \\
\text { tahun } 2013\end{array}$ & 34 & 409 & 93 & 536 & \\
\hline
\end{tabular}

Sumber: Juanda (2007), Pramusinto (2010) dalam Kuncoro (2012), Depdagri (2009) dalam Ratnawati (2010), dan Kemendagri (2013).

Perubahan politik yang terjadi di Indonesia dan krisis moneter tahun 1998 mengubah Indonesia dari salah satu negara paling sentralisasi menjadi salah satu negara paling demokratis dan terdesentralisasi (Butt, 2010: 1). Proses desentralisasi dan penambahan provinsi baru, kabupaten, dan unit pemerintah daerah yang lebih rendah di luar Pulau Jawa adalah reaksi terhadap ketidaksetaraan dan ketidakadilan yang dirasakan. Perubahan ini muncul sebagai hasil dari suatu kompleksitas kekuatan politik, sosial, budaya, dan ekonomi (Charas, 2004 dalam Booth, 2010: 53). Melalui kebijakan desentralisasi dan otonomi daerah dengan implikasi pemekaran wilayah, maka pemekaran wilayah dapat dipandang sebagai salah satu bentuk pengembangan wilayah sehingga diharapkan dapat memperkecil kesenjangan antarwilayah serta dapat menyeimbangkan pertumbuhan dan perkembangan antarwilayah (Muta'ali, 2011). Sejak berlakunya otonomi daerah terjadi penambahan provinsi, kabupaten, dan kota dari tahun 1999-2013 seperti tersaji pada Tabel 1.

Kebijakan desentralisasi dan otonomi daerah telah mendorong terbentuknya provinsi, kabupaten, dan kota sebagai suatu wilayah. Kondisi ini menciptakan perbedaan antara daerah provinsi, kabupaten, dan kota pemekaran, di mana ada daerah yang penduduk/kegiatan terkonsentrasi pada suatu tempat dan yang kurang terkonsentrasi. Tempat terkonsentrasi dikenal dengan berbagai istilah, kota, pusat perdagangan, pusat industri, simpul industri, pusat perdagangan, daerah perkotaan atau daerah nodal. Sedang daerah luar pusat konsentrasi dinamakan dengan berbagai istilah, seperti daerah pedalaman, daerah pertanian, daerah pedesaan atau bahkan disebut sebagai wilayah belakang (Tarigan, 2005).

Fenomena terciptanya daerah nodal tidak hanya di wilayah provinsi, namun terjadi di wilayah kabupaten/kota, di mana biasanya pusat kegiatan ekonomi terjadi di daerah kota. Fenomena khususnya terjadi pada kabupaten-kabupaten yang mempunyai wilayah yang luas. Kabupaten dengan wilayah yang luas biasanya membagi dua wilayah secara administratif, yaitu wilayah kota (kotamadya) dan wilayah kabupaten. Wilayah kota ini kemudian dijadikan sebagai pusat kegiatan ekonomi (pusat pertumbuhan), sedang kabupaten sebagai daerah hinterland (Sutikno dan Maryunani, 2007). Pembangunan yang terpolarisasi (polarized development) justru dapat memberikan manfaat bagi wilayah pertumbuhan dan daerah belakang/ daerah sekitarnya (Dawkins, 2003).

Kebijakan desentralisasi dan otonomi daerah yang dilaksanakan di Indonesia dengan strategi pemekaran wilayah merupakan fenomena pembentukan provinsi, kabupaten, dan kota, diharapkan mampu 
Tabel 2. Perkembangan PDRB Per Kapita Kabupaten/Kota Wilayah Priangan Timur Tahun 2009-2013

\begin{tabular}{|c|l|c|c|c|c|c|}
\hline \multirow{2}{*}{ No. } & \multirow{2}{*}{ Kabupaten/Kota } & \multicolumn{5}{|c|}{ PDRB Per Kapita (Rp Juta) } \\
\cline { 3 - 7 } & & $\mathbf{2 0 0 9}$ & $\mathbf{2 0 1 0}$ & $\mathbf{2 0 1 1}$ & $\mathbf{2 0 1 2}$ & $\mathbf{2 0 1 3}$ \\
\hline 1. & Kota Tasikmalaya & $5.867 .833,53$ & $6.103 .765,76$ & $6.372 .765,87$ & $6.687 .108,43$ & $7.083 .021,00$ \\
\hline 2. & Kab. Tasikmalaya & $3.083 .272,84$ & $3.180 .496,59$ & $3.392 .114,12$ & $3.480 .611,88$ & $3.625 .943,04$ \\
\hline 3. & Kab. Garut & $4.461 .515,17$ & $4.625 .324,92$ & $4.798 .579,77$ & $4.951 .144,73$ & $5.145 .602,01$ \\
\hline 4. & Kab. Ciamis & $4.497 .431,00$ & $4.709 .177,00$ & $5.005 .806,29$ & $5.246 .001,12$ & $5.492 .498,01$ \\
\hline 5. & Kota Banjar & $4.184 .032,00$ & $4.281 .007,00$ & $4.430 .452,00$ & $4.618 .575,00$ & $4.822 .530,00$ \\
\hline 6. & Kab. Pangandaran & $5.165 .348,36$ & $5.401 .598,82$ & $5.637 .849,28$ & $5.874 .099,74$ & $6.123 .574,99$ \\
\hline
\end{tabular}

Sumber: BPS Kota Tasikmalaya dan Banjar (2009-2014) dan BPS Kabupaten Tasikmalaya, Kabupaten Garut, Kabupaten Ciamis, dan Kabupaten Pangandaran (2009-2014).

menumbuhkan dan mengembangkan pusat-pusat pertumbuhan ekonomi pada suatu wilayah sehingga mendorong pertumbuhan dan perkembangan ekonomi bagi daerah sekitarnya. Sebagaimana halnya dengan Kota Tasikmalaya yang dimekarkan tahun 2001 dari Kabupaten Tasikmalaya. Proses pemekaran wilayah tersebut mampu mendorong dan mengembangkan perekonomian wilayah, sehingga memberikan dampak penyebaran (spread effect) maupun sebagai generator bagi kegiatan perekonomian wilayah sekitar.

Tabel 2 memperlihatkan sebagai kota sebagai hasil pemekaran, PDRB per kapita Kota Tasikmalaya kurun waktu tahun 2009-2013 lebih besar dibandingkan daerah sekitarnya. Kondisi ini berpengaruh dan menjadi daya tarik ekonomi bagi masyarakat kabupaten/kota yang ada di sekitarnya.

Selain itu, pada tabel 3 memperlihatkan Kota Tasikmalayadalamlimatahunmengalamipertumbuhan ekonomi yang cukup pesat. Hal ini menunjukkan bahwa kebijakan otonomi daerah memberikan dampak yang signifikan bagi perkembangan perekonomian wilayah Kota Tasikmalaya sehingga dapat memberikan efek penyebaran bagi pertumbuhan ekonomi daerah sekitarnya.

Berdasarkan data tersebut menunjukkan bahwa dari sisi PDRB ADHK Kota Tasikmalaya tahun 20092013 lebih kecil dibandingkan dengan Kabupaten Tasikmalaya dan Kabupaten Garut. Namun penetapan Kota Tasikmalaya, sebagai pusat kegiatan wilayah (PKW) Priangan Timur yang tertuang dalam Rencana Tata Ruang Wilayah Nasional (RTRWN) dan Rencana Tata Ruang Wilayah (RTRW) Provinsi Jawa Barat, telah menempatkan posisi Kota Tasikmalaya cukup strategis dibandingkan dengan daerah sekitarnya. Dikatakan strategis karena berada pada bagian timur Provinsi Jawa Barat yang merupakan jalur perlintasan selatan tujuan Jakarta-Jogya dan Surabaya. Selain itu, sebagai daerah penyangga, khususnya pada kawasan Priangan Timur yang berbatasan langsung dengan Provinsi Jawa Tengah dan diharapkan mampu memberikan efek penyebaran serta menggerakkan kegiatan ekonomi bagi daerah-daerah sekitarnya, antara lain Kabupaten Tasikmalaya, Kabupaten Garut, Kabupaten Ciamis, Kota Banjar, dan Kabupaten Pangandaran. Berdasarkan hal tersebut, maka perlu

Tabel 3. Perkembangan Laju Pertumbuhan Ekonomi Kabupaten/Kota Wilayah Priangan Timur Tahun 2009-2013

\begin{tabular}{|c|c|c|c|c|c|c|}
\hline \multirow{2}{*}{ No. } & \multirow{2}{*}{ Kabupaten/Kota } & \multicolumn{5}{|c|}{ Laju Pertumbuhan Ekonomi (Persen) } \\
\hline & & 2009 & 2010 & 2011 & 2012 & 2013 \\
\hline 1. & Kota Tasikmalaya & 5,72 & 5,73 & 5,81 & 5,89 & 5,92 \\
\hline 2. & Kabupaten Tasikmalaya & 4,15 & 4,27 & 4,32 & 4,32 & 4,46 \\
\hline 3. & Kabupaten Garut & 5,57 & 5,34 & 5,48 & 4,61 & 4,82 \\
\hline 4. & Kabupaten Ciamis & 4,92 & 5,07 & 5,11 & 4,99 & 5,02 \\
\hline 5. & Kota Banjar & 5,13 & 5,28 & 5,35 & 5,26 & 5,34 \\
\hline 6. & Kabupaten Pangandaran & - & - & 4,62 & 4,79 & 4,85 \\
\hline
\end{tabular}

Sumber: BPS Kota Tasikmalaya dan Banjar (2009-2013) dan BPS Kabupaten Tasikmalaya, Kabupaten Garut, Kabupaten Ciamis, dan Kabupaten Pangandaran (2009-2014). 
Tabel 4. Perkembangan PDRB ADHK Tahun 2000 Kabupaten/Kota Wilayah Priangan Timur Tahun 2009-2013

\begin{tabular}{|c|l|r|r|r|r|r|}
\hline \multirow{2}{*}{ No. } & \multirow{2}{*}{ Kabupaten/Kota } & \multicolumn{5}{|c|}{ PDRB ADHK Tahun 2000 } \\
\cline { 3 - 7 } & & $\mathbf{2 0 0 9}$ & \multicolumn{1}{c|}{$\mathbf{2 0 1 0}$} & \multicolumn{1}{c|}{$\mathbf{2 0 1 1}$} & \multicolumn{1}{c|}{$\mathbf{2 0 1 2}$} & $\mathbf{2 0 1 3}$ \\
\hline 1. & Kota Tasikmalaya & $3.668,63$ & $3.878,72$ & $4.104,24$ & $4.345,86$ & $4.603,15$ \\
\hline 2. & Kabupaten Tasikmalaya & $5.291,16$ & $5.517,02$ & $5.755,15$ & $5.995,40$ & $6.262,92$ \\
\hline 3. & Kabupaten Garut & $10.568,75$ & $11.133,63$ & $11.743,83$ & $12.284,54$ & $12.876,41$ \\
\hline 4. & Kabupaten Ciamis & $7.071,05$ & $7.426,48$ & $7.809,16$ & $8.198,90$ & $8.610,62$ \\
\hline 5. & Kota Banjar & 712,21 & 749,85 & 789,96 & 831,48 & 875,90 \\
\hline 6. & Kabupaten Pangandaran & & - & $2.151,97$ & $2.255,07$ & $2.364,50$ \\
\hline
\end{tabular}

Sumber: BPS Kota Tasikmalaya dan Banjar (2009-2014) dan BPS Kabupaten: Tasikmalaya, Garut, Ciamis, dan Pangandaran (2009-2014).

dianalisis potensi Kota Tasikmalaya sebagai pusat pertumbuhan dalam kaitannya memberikan efek penyebaran bagi perekonomian wilayah kabupaten/ kota sekitarnya.

\section{B. Permasalahan}

Pemekaran wilayah merupakan implikasi dari penerapan desentralisasi dan otonomi daerah sebagaimana amanah Undang-Undang No. 22 Tahun 1999. Implementasi pemekaran wilayah sebagai suatu bentuk percepatan pembangunan maupun peningkatan kesejahteraan masyarakat ternyata tidak selalu memberikan dampak positif tetapi tidak juga negatif terhadap perekonomian wilayah. Praktikno (2007) dalam Ratnawati (2009) mengatakan bahwa pemekaran wilayah memiliki "wajah ganda", yaitu ada sisi positif dan sisi negatif. Manfaat dan kerugiannya sangat tergantung pada sudut pandang siapa, baik pemerintah daerah ataupun pusat. Jika dari sudut pandang daerah, pemekaran wilayah memberikan dampak positif bagi perkembangan percepatan pembangunan (Nugroho, 2011), namun dari sudut pandang pemerintah pusat, pemekaran wilayah justru banyak mengalami kegagalan dalam implementasinya (Bappenas dan UNDP, 2008).

Berbagai permasalahan (bad practice) timbul sejak adanya kebijakan pemekaran wilayah, seperti konflik di tingkat lokal yang mencakup isu kesukuan dan/atau keagamaan, perebutan wilayah, dan masalah letak ibu kota pemekaran, hingga perebutan asset (Pamungkas, 2007; Agustino dan Yussof, 2008). Hal ini muncul salah satunya disebabkan semangat kedaerahan yang sangat menonjolkan kesukuan tanpa mau berinteraksi dengan suku lain (Nugroho, 2011). Pada sisi hukum, muncul fenomena berupa kecenderungan suatu daerah untuk mengatur segala yang ada di wilayah pemerintahannya melalui perda karena euforia otonomi daerah. Tidak jarang suatu daerah otonom baru terkadang membuat perda yang melampaui batas wilayahnya (Butt, 2010).
Di balik berbagai permasalahan yang ditimbulkan tersebut, pemekaran wilayah juga menghasilkan hal yang positif bagi daerah, seperti Kabupaten Jembrana dengan pembebasan biaya sekolah untuk sekolah negeri, pemberian beasiswa dari SD-SMA, dan asuransi kesehatan masyarakat. Kabupaten Sragen sukses dengan kantor pelayanan terpadu. Kabupaten Musi Banyuasin menyediakan fasilitas kuliah gratis di Politeknik Sekayu dan Akademi Perawat Muba (Nugroho, 2011). Kabupaten Kutai Timur, Kabupaten Palawan Riau, dan Kabupaten Way Kanan Lampung banyak menarik investor karena SDA yang melimpah dan berhasil membangun sistem pelayanan satu atap. Kabupaten Tanah Bumbu di Kalimantan Selatan, berhasil membangun infrastruktur hingga ke pelosok perdesaan dan memberikan subsidi pembangunan desa sebesar Rp250 juta per desa per tahun. Dan Kota Metro Lampung berhasil mengembangkan sektor jasa dengan baik, seperti pendidikan dan perdagangan (Ratnawati, 2009).

Selain menghasilkan bad practice dan best practice, pemekaran wilayah timbul karena isu pemerintahan yang sentralistik, kesenjangan pembangunan wilayah, dan pemerataan hasil pembangunan antara Pulau Jawa-luar Pulau Jawa maupun antara Kawasan Indonesia Timur dan Kawasan Indonesia Barat (Booth, 2011; Kuncoro, 2002; Sjafrizal, 1997; dan Nazara, 1994). Oleh sebab itu, ketimpangan regional dapat dirasakan dalam pertumbuhan ekonomi rendah, maupun ketimpangan yang berkaitan dengan prasarana ekonomi, sosial politik, dan pembangunan fisik lainnya.

Penelitian ini mencoba melihat bahwa kebijakan desentralisasi dan otonomi daerah (pemekaran wilayah), dengan studi kasus di Kota Tasikmalaya pada tahun 2001, merupakan hal yang sangat penting dalam meningkatkan dan mendorong strategi pusat-pusat pertumbuhan dengan mengembangkan hubungan ekonomi antara pusat- 
pusat pertumbuhan wilayah dan pertumbuhan daerah sekitarnya. Perkembangan perekonomian wilayah yang begitu pesat dapat meningkatkan hubungan/interaksi ekonomi dan daya tarik wilayah bagi daerah sekitarnya. Kondisi tersebut diharapkan dapat mendorong dan mengembangkan Kota Tasikmalaya menjadi pusat pertumbuhan ekonomi yang dapat memberikan pengaruh dan dampak bagi daerah-daerah sekitarnya.

Berdasarkan latar belakang dan permasalahan tersebut, maka rumusan masalah dalam penelitian adalah sebagai berikut:

1. bagaimana perkembangan struktur perekonomian Kota Tasikmalaya dibandingkan dengan daerah sekitarnya?

2. sektor-sektor ekonomi apa saja yang menjadi sektor unggulan dan daya saing wilayah Kota Tasikmalaya dibandingkan dengan daerah sekitarnya?

\section{Tujuan}

Berdasarkan permasalahan tersebut, maka tujuan penelitian ini adalah menganalisis (1) perkembangan struktur perekonomian wilayah Kota Tasikmalaya dibandingkan dengan daerah sekitarnya dan (2) sektor unggulan yang menjadi daya saing perekonomian wilayah Kota Tasikmalaya dibandingkan dengan daerah sekitarnya.

\section{KERANGKA TEORI}

\section{A. Landasan Teoritik Pemekaran Wilayah}

Pemekaran wilayah pada dasarnya dilandasi oleh teori tentang lokasi dan wilayah. Teori lokasi dan wilayah berhubungan dengan keruangan (Tarigan, 2005). Dengan demikian dapat dikatakan bahwa pemekaran wilayah sebagai suatu proses pemecahan wilayah (dari satu wilayah membentuk wilayah lain) memiliki sifat-sifat keruangan. Mengacu dari teori lokasi dan wilayah tersebut, ide dasar dari konsep pemekaran wilayah pada umumnya lebih banyak dipengaruhi dan diadopsi dari teori lokasi pusat (central place theory). Teori lokasi pusat pertama kali di kemukakan oleh Walter Christaller tahun 1933, kemudian diperluas dan dikembangkan oleh August Losch tahun 1940. Teori lokasi pusat berasumsi bahwa suatu tempat merupakan pusat pemasaran atau pusat pelayanan yang membentuk suatu hierarki yang teratur. Christaller memperkenalkan konsep threshold, yakni ukuran atau besaran minimum volume pasar yang dipersyaratkan untuk menyelenggarakan barang dan jasa tertentu dan range (jarak maksimum bagi konsumen untuk membeli barang dan jasa). Jarak yang terlalu jauh dapat menyebabkan konsumen tidak lagi berminat membeli barang/jasa tersebut. Dari pusat kegiatan besaran range menjadi batasan bagi luas daerah pelayanan pasar (Setiono, 2011).

Prinsip dasar teori lokasi pusat Christaller adalah struktur hubungan pusat-pusat kegiatan dengan sistem $\mathrm{k}=3$ (role of threes) atas dasar 3 prinsip, yaitu prinsip pasar (the market principle) digambarkan dengan sistem $\mathrm{k}=3$. Prinsip transportasi (the tranpostation principle) digambarkan dengan model $\mathrm{k}=4$, di mana lokasi pusat terbentuk sebagai jalur transportasi/traffic yang lurus dan menyebar dari titik pusat. Untuk pusat yang ordenya lebih tinggi mendominasi lokasi pasar dari pusat-pusat yang ordenya lebih rendah. Prinsip administratif mengatur hierarki pusat dari sudut pandang politik atau administrasi dan digambarkan dengan model $k=7$. Prinsip ini mengatur seluruh pusat-pusat dari orde yang lebih rendah dimasukkan ke dalam pusat yang berorde tertinggi (Setiono, 2011).

Pemekaran wilayah dipandang sebagai bentuk pendekatan model lokasi pusat (central place). Jika melihat syarat pembentukan provinsi, maka paling sedikit 5 kabupaten/kota, pembentukan kabupaten paling sedikit 5 kecamatan, dan pembentukan kota paling sedikit 4 kecamatan. Apabila dihubungkan dengan prinsip-prinsip dari teori lokasi pusat Christaller, pemekaran wilayah sebagai pemecahan dari satu kabupaten menjadi dua atau lebih kabupaten/kota yang baru, di mana kabupaten/ kota baru cenderung sebagai atau menjadi suatu lokasi pusat baru yang mampu atau dapat melayani daerah belakang (hinterland) dan mendekatkan jarak pelayanan.

\section{B. Pemekaran Wilayah, Desentralisasi, dan Otonomi Daerah}

Pemekaran wilayah dapat dilihat sebagai bagian dari proses penataan daerah atau territorial reform atau administrative reform, yaitu "management of the size, shape and hierarchy of local government units for the purpose of achieving political and administrative goals" (reformasi teritorial atau reformasi administrasi, yaitu pengelolaan ukuran, bentuk, dan hierarki satuan pemerintah daerah untuk maksud mencapai atau melaksanakan tujuan politik dan administrasi). Penataan daerah umumnya mencakup pemekaran, penggabungan, dan penghapusan daerah (Ratnawati, 2010). Kebijakan territorial reform menjadi preferensi beberapa negara dan terdapat tiga varian dari bentuk ini, yaitu (1) pemekaran (proliferation) daerah. Kebijakan ini menjadi pilihan bagi negara-negara berkembang (Pakistan, Filipina, Nigeria, Uganda, Kenya) yang mengutamakan kedekatan geografi (geographic proximity), (2) penggabungan (amalgamation) daerah. Kebijakan ini dipilih negara-negara maju 
(Victoria-Australia, Jepang, Kanada, Swedia) yang berorientasi pada prinsip ekonomi (efisiensi) dalam penyelenggaraan pemerintahan, dan (3) bentuk campuran antara pemekaran dan penggabungan. Negara-negara yang menganut kebijakan ini menyesuaikan dengan kondisi politik dan ekonomi yang ada. Pemilihan territorial reform melalui pemekaran wilayah tidak tergantung pada bentuk negara apakah federal atau kesatuan (Tryatmoko, 2010).

Dari sudut pandang desentralisasi, pemekaran wilayah merupakan pelaksanaan asas desentralisasi (Ratnawati, 2010). Cheema dan Rondinelli (2007) mendefinisikan decentralization was defined as the transfer of authority, responsibility, and resourcesthrough deconcentration, delegation, or devolutionfrom the center to lower levels of administration. Disebutkan bahwa pemerintah dewasa ini menerapkan 3 bentuk desentralisasi, yaitu (1) "deconcentration, sought to shift administrative responsibilities from central ministries and departments to regional and local administrative levels by establishing field offices of national departments and transferring some authority for decision making to regional field staff, (2) devolution aimed to strengthen local governments by granting them the authority, responsibility, and resources to provide services and infrastructure, protect public health and safety, and formulate and implement local policies, dan (3) delegation, national governments shifted management authority for specific functions to semi-autonomous or parastatal organizations and state enterprises, regional planning and area development agencies, and multiand single-purpose public authorities" (Cheema and Rondinelli, 2007). Akibat prinsip tersebut dikenal adanya daerah otonom dan wilayah administratif (Kuncoro, 2004).

Secara teoritis kata otonomi berasal dari Bahasa Yunani "outonomous" yang berarti pemerintahan sendiri (auto $=$ sendiri, nomus $=$ pemerintahan). Hal ini mempunyai makna kemandirian untuk mengatur dan mengurus rumah tangganya sendiri, dapat disebut pula penyerahan penuh kepada daerah otonom untuk melaksanakan urusan rumah tangga. Pada dasarnya pengertian otonomi menyangkut dengan dua hal pokok, yaitu kewenangan untuk membuat hukum sendiri (own laws) dan kebebasan untuk mengatur pemerintahan sendiri (self government) (Sjafrizal, 2008). Hidayat (2000) menyebutkan ada tiga alasan pokok otonomi daerah diperlukan, yaitu (1) political equality, meningkatkan partisipasi politik pada tingkat daerah, penting artinya untuk meningkatkan demokratisasi dalam pengelolaaan negara, (2) local accountability, meningkatkan kemampuan dan tanggung jawab pemerintah daerah dalam mewujudkan hak dan aspirasi masyarakat di daerah, dalam rangka meningkatkan pertumbuhan ekonomi dan kesejahteraan sosial di daerah, dan (3) local responsiveness, yaitu meningkatkan tanggung jawab pemerintah daerah terhadap masalahmasalah sosial ekonomi yang terjadi di daerahnya (Agusniar, 2006).

\section{Pusat Pertumbuhan}

Konsep dasar pusat pertumbuhan berasal dari teori kutub pertumbuhan yang pertama kali dikemukakan oleh Francoise Perroux tahun 1955 dengan Pole de Croissance. Asumsinya adalah "growth does not appear everywhere at the same time; it appears at points or poles of growth with varying intensity; it spreads along various channels and with differing overall effects on the whole economy (Parr, 1999). Dasar teori dari kutub pertumbuhan adalah kegiatan ekonomi di dalam suatu daerah cenderung terpusat pada satu titik lokal (pusat). Lebih lanjut Perroux mendefinisikan kutub pertumbuhan sebagai "as a field of forces, economic space consists of centers (pole and foci) from which centrifugal forces emanate and to which forces are attracted. Each center being a center of attraction and repulsion has its proper field, which is a set in the field of all other centers" (Monsted, 1974).

Higgins and Salvoie (2005) memberikan pengertian "the growth pole is a set (of economis activities) that has to introduce the growth of another set. Adanya sekumpulan kegiatan ekonomi akan menumbuhkan kegiatan ekonomi lainnya. Meskipun demikian, suatu pusat pertumbuhan yang memengaruhi kegiatan ekonomi akan semakin berkurang jika semakin menjauh dari pusat pertumbuhan. Pusat dapat dikatakan sebagai titik pertumbuhan, sedangkan daerah sekitarnya yang masih terpengaruh adalah daerah pengaruhnya. Pusat pertumbuhan dapat diartikan dengan dua cara, yaitu pertama secara fungsional, pusat pertumbuhan dijelaskan sebagai suatu lokasi konsentrasi kelompok usaha atau cabang industri yang karena sifat hubungannya memiliki unsur-unsur kedinamisan sehingga mampu menstimulasi kehidupan ekonomi, baik ke dalam maupun keluar (daerah belakangnya). Kedua, secara geografis, pusat pertumbuhan adalah suatu lokasi yang banyak memiliki fasilitas dan kemudahan sehingga menjadi pusat daya tarik, berbagai macam usaha untuk melakukan kegiatan ekonomi di tempat tersebut dan masyarakat senang datang memanfaatkan fasilitas yang ada di kota tersebut, walaupun kemungkinan tidak ada interaksi antara usaha-usaha tersebut (Tarigan, 2005).

Suatu kota dikatakan sebagai pusat pertumbuhan apabila memiliki empat ciri-ciri pusat pertumbuhan, 
yaitu (1) ada hubungan internal dari berbagai macam kegiatan yang memiliki nilai ekonomi, ada keterkaitan antara satu sektor dengan sektor lainnya sehingga apabila ada satu sektor yang tumbuh akan mendorong sektor lainnya, karena saling terkait, (2) ada efek pengganda: keberadaan sektor-sektor yang saling terkait dan saling mendukung menciptakan efek pengganda, (3) terdapat konsentrasi geografis, konsentrasi geografis dari berbagai sektor atau fasilitas, selain bisa menciptakan efisiensi di antara sektor-sektor yang saling membutuhkan, juga meningkatkan daya tarik dari kota tersebut, dan (4) bersifat mendorong daerah belakangnya, berarti kota dan wilayah belakangnya terdapat hubungan yang harmonis. Kota membutuhkan bahan baku dari wilayah belakangnya dan menyediakan berbagai kebutuhan wilayah belakangnya untuk dapat mengembangkan diri (Tarigan, 2005; Adisasmita, 2008).

Konsep lain yang berhubungan dengan pusat pertumbuhan adalah konsep wilayah nodal. Konsep ini memandang suatu wilayah secara dikotomis (terbagi atas dua bagian) yang didasarkan atas asumsi bahwa suatu wilayah diumpamakan sebagai suatu "sel hidup" yang mempunyai plasma dan inti. Inti (pusat simpul) adalah pusat-pusat pelayanan dan atau permukiman sedang plasma adalah daerah belakang (periphery/hinterland), yang mempunyai sifat-sifat tertentu dan mempunyai hubungan fungsional (Rustiadi, et al., 2009: 34). Lebih lanjut Richardson (1969) menyebutkan konsep wilayah nodal lebih fokus pada peran pengendalian atau pengaruh central atau pusat (node) serta hubungan ketergantungan pusat dan elemen-elemen sekelilingnya dibandingkan soal batas wilayah (Rustiadi, et al., 2009: 34).

Konsep-konsep yang sama dengan teori kutub pertumbuhan Perrox juga digunakan oleh penulis lain, seperti core region (wilayah inti), growth areas (daerah-daerah pertumbuhan), growth point (titik-titik pertumbuhan), growth and development poles (kutub-kutub pertumbuhan/pengembangan), growth centers (pusat-pusat pertumbuhan) pada prinsipnya mendorong perkembangan suatu wilayah, serta sudah memasukkan dimensi geografis dan lokasi sedang konsep kutub pertumbuhan tanpa suatu dimensi geografis yang spesifik (Nurzaman, 2012).

\section{METODOLOGI}

\section{A. Objek Penelitian}

Undang-Undang No. 22 Tahun 1999 tentang Pemerintahan Daerah efektif mulai berlaku sejak tahun 2001. Kota Tasikmalaya pada awalnya adalah kota administratif selama 25 tahun dan berlakunya
Undang-Undang tersebut menjadi momentum berubah secara resmi menjadi daerah otonom baru, yaitu Kota Tasikmalaya. Konsekuensinya, Kota Tasikmalaya mempunyai kewenangan untuk mengatur rumah tangga sendiri melalui UndangUndang No. 10 Tahun 2001 tertanggal 17 Oktober 2001.

Pemilihan Kota Tasikmalaya sebagai lokasi penelitian ini karena kota ini memiliki karakteristik sebagai pusat/kutub pertumbuhan. Kebijakan desentralisasi dan otonomi daerah yang tepat akan menyebarkan pertumbuhan pusat-pusat pertumbuhan regional dan mengarah pada pengembangan daerah sekitarnya. Kota Tasikmalaya sebagai kota hasil pemekaran berada pada suatu kawasan yang disebut Priangan Timur dan memiliki beberapa daerah hinterland.

\section{B. Variabel Penelitian}

Variabel penelitian dalam penelitian ini meliputi Produk Domestik Regional Bruto Atas Dasar Harga Konstan (PDRB ADHK 2000), PDRB per kapita ADHK, dan pertumbuhan ekonomi. Variabel-variabel tersebut merupakan indikator yang menunjukkan pencapaian dan dampak kebijakan dari pelaksanaan program pembangunan, termasuk menjadi indikator perkembangan perekonomian suatu wilayah.

\section{Metode Pengumpulan Data}

Metode pengumpulan data yang dilakukan meliputi:

\section{1) Metode Dokumentasi}

Metode dokumentasi dilakukan untuk mendapatkan data kabupaten/kota: Kota Tasikmalaya, Kabupaten Tasikmalaya, Kabupaten Garut, Kabupaten Ciamis, Kota Banjar dan Kabupaten Pangandaran selama 5 tahun terakhir. Data tersebut mencakup PDRB ADHK tahun 2000 untuk periode tahun 20092013, PDRB per kapita ADHK periode tahun 2009-2013, dan pertumbuhan ekonomi tahun 2009-2013, baik yang bersumber dari BPS maupun dari Bappeda serta instansi terkait dengan penelitian ini.

\section{2) Metode Wawancara}

Metode wawancara dilakukan kepada pihakpihak yang terkait dengan penelitian ini, yaitu Bappeda maupun SKPD lain dari 6 kabupaten/ kota se-Priangan Timur (Kota Tasikmalaya, Kabupaten Tasikmalaya, Kabupaten Garut, Kabupaten Ciamis, Kota Banjar, dan Kabupaten Pangandaran). 
Tabel 5. Matrik Klasifikasi Kabupaten/Kota Berdasarkan Tipologi Klassen

\begin{tabular}{|c|c|c|}
\hline Laju Pertumbuhan (r) & $\mathbf{y}_{\mathbf{i}}<\mathbf{y}$ & $\mathbf{y}_{\mathbf{i}}>\mathbf{y}$ \\
\hline $\mathbf{r}_{\mathrm{i}}>\mathbf{r}$ & $\begin{array}{c}\text { Daerah berkembang } \\
\text { cepat (growing region) }\end{array}$ & $\begin{array}{c}\text { Daerah maju dan cepat tumbuh } \\
\text { (rapid growth region) }\end{array}$ \\
\hline$r_{i}<\mathbf{r}$ & $\begin{array}{c}\text { Daerah relatif tertinggal } \\
\text { (relatively backward region) }\end{array}$ & $\begin{array}{c}\text { Daerah maju tapi } \\
\text { tertekan (retarded region) }\end{array}$ \\
\hline
\end{tabular}

Keterangan: $\boldsymbol{y}_{i}$ adalah rata-rata PDRB per kapita kabupaten/kota $\mathbf{i}$ y adalah rata-rata PDRB per kapita kabupaten/ kota; $\boldsymbol{r}_{i}$ adalah rata-rata laju pertumbuhan ekonomi kabupaten/kota i; $\boldsymbol{r}$ adalah rata-rata laju pertumbuhan ekonomi kabupaten/kota.

\section{3) Metode Analisis}

Metode analisis dalam penelitian ini meliputi:

\section{a. Analisis Tipologi Klassen}

Tipologi Klassen digunakan untuk mengetahui gambaran tentang pola dan struktur pertumbuhan ekonomi daerah dan membagi daerah dalam dua indikator utama, pertumbuhan ekonomi, dan pendapatan per kapita (Kuncoro, 2013). Tipologi Klassen membagi daerah dalam empat klasifikasi, yaitu daerah maju dan cepat tumbuh (high growth, high income), daerah berkembang cepat (high growth but low income), daerah maju tapi tertekan (high income but low growth), daerah relatif tertinggal (low growth and low income) (Kuncoro, 2013).

Alat analisis tipologi Klassen digunakan untuk melihat pertumbuhan pembangunan ekonomi suatu daerah serta memetakan atau menggolongkan daerah-daerah yang mengalami pertumbuhan ekonomi dan pendapatan per kapita, yang diukur dengan membandingkan nilai rata-rata provinsi.

b. Indeks Diversity Entropy (IDE)

Indeks Diversitas Entropi (IDE) dipakai untuk mengukur maju/berkembangnya atau tidak maju/tidak berkembangnya perekonomian wilayah suatu daerah, jika hasilnya mendekati 1, wilayah tersebut semakin berkembang, jika hasilnya mendekati 0 , wilayah tersebut tidak/kurang berkembang. Semakin besar nilai entropi berarti suatu wilayah dianggap semakin berkembang dan sebaliknya (Pribadi, et al., tanpa tahun). Persamaan umum dalam perhitungan indeks diversitas entropi adalah:

$$
S=-\sum_{i=1}^{n} \sum_{j=i}^{n} P_{i} I n P_{i}
$$

Di mana: $S=$ nilai entropi; $P_{i}=$ nilai rasio antara aktivitas/sektor ekonomi ke-i dibagi jumlah total aktivitas/sektor ekonomi; $\mathrm{i}=$ kategori aktivitas/sektor ekonomi ke-i; $\mathrm{j}=$ kategori wilayah ke-j (kab/kota); $\mathrm{n}=$ total aktivitas/sektor ekonomi.

Dalam suatu wilayah perkembangan ekonominya dapat berkembang maju atau sebaliknya. Untuk mengukur maju atau berkembangnya atau tidak maju atau tidak berkembangnya perekonomian wilayah dapat dilihat dari IDE-nya. Prinsip pengertian indeks entropi adalah semakin beragam aktivitas atau semakin luas jangkauan spasial, maka semakin tinggi entropi wilayah, artinya wilayah tersebut semakin berkembang. Nilai IDE ditujukan untuk menghitung tingkat keberagaman dan keberimbangan aktivitas atau sektor ekonomi di suatu wilayah. Semakin berimbang komposisi berbagai aktivitas atau sektor ekonomi tersebut nilai IDE juga semakin besar ini berarti suatu wilayah dapat dianggap semakin maju atau berkembang.

\section{c. Analisis Location Quotient (LQ)}

Analisis Location Quotient (LQ) salah satu metode pengukuran tidak langsung untuk mengetahui suatu sektor dalam suatu wilayah merupakan sektor basis atau non basis (Budiharsono, 2001). Riyadi dan Bratakusumah (2004) analisis LQ dimaksudkan untuk mengetahui gambaran umum mengenai kemampuan sektor-sektor pembangunan di suatu wilayah dalam mendukung proses pembangunan daerah, kemampuan sektor-sektor pembangunan dalam suatu daerah dibandingkan sektorsektor pembangunan yang ada di daerah yang lebih besar. Rumus LQ adalah: 


$$
L Q_{i j}=\frac{X_{i j} / X_{i}}{X_{. j} / X_{.}}
$$

Di mana $\mathrm{LQ}_{\mathrm{ij}}$ adalah nilai $\mathrm{LQ}$ untuk sektor tertentu daerah $\mathrm{i} ; \mathrm{X}_{\mathrm{ij}}$ adalah nilai sektor tertentu kabupaten/kota i; $X_{i}$ adalah nilai total sektor kabupaten/kota $\mathrm{i} ; \mathrm{X}_{\mathrm{j}}$ adalah nilai sektor tertentu provinsi; X.. adalah nilai total sektor provinsi. Ukuran analisis LQ menurut Bendavid-Val dalam Kuncoro (2002) adalah LQ > 1 menunjukkan bahwa sektor tersebut merupakan sektor basis atau unggulan karena mampu meningkatkan dan mengembangkan daerah atau wilayah sebagai refleksi dari adanya kelebihan produksi yang dipasarkan ke daerah lain. $\mathrm{LQ}=1$ menunjukkan bahwa sektor tersebut bukan sektor basis dan hanya mampu memenuhi kebutuhan lokal daerah, tetapi memiliki potensi untuk menjadi sektor basis.
LQ $<1$ menunjukkan bahwa sektor tersebut bukan sektor basis atau unggulan, karena belum cukup memenuhi kebutuhan lokal, maka ada kecenderungan untuk mengimpor dari luar daerah (Kuncoro, 2002).

Diharapkan dengan pemilihan alat analisis tipologi Klassen, IDE, dan LQ dapat menjawab permasalahan dan tujuan penelitian.

\section{HASIL DAN PEMBAHASAN}

\section{Analisis Tipologi Klassen}

Berdasarkan analisis tipologi Klassen dari 27 kabupaten/kota se-Provinsi Jawa Barat tahun 20092013, diketahui sumbu horizontal menunjukkan ratarata pertumbuhan ekonomi sebesar 5,37 persen dan sumbu vertikal menunjukkan rata-rata PDRB ADHK tahun 2000 sebesar Rp12.236,09 miliar (Gambar 1).

Hasil analisis tipologi Klassen kabupaten/kota seProvinsi Jawa Barat tahun 2009-2013, menunjukkan klasifikasi daerah maju dan cepat tumbuh ada

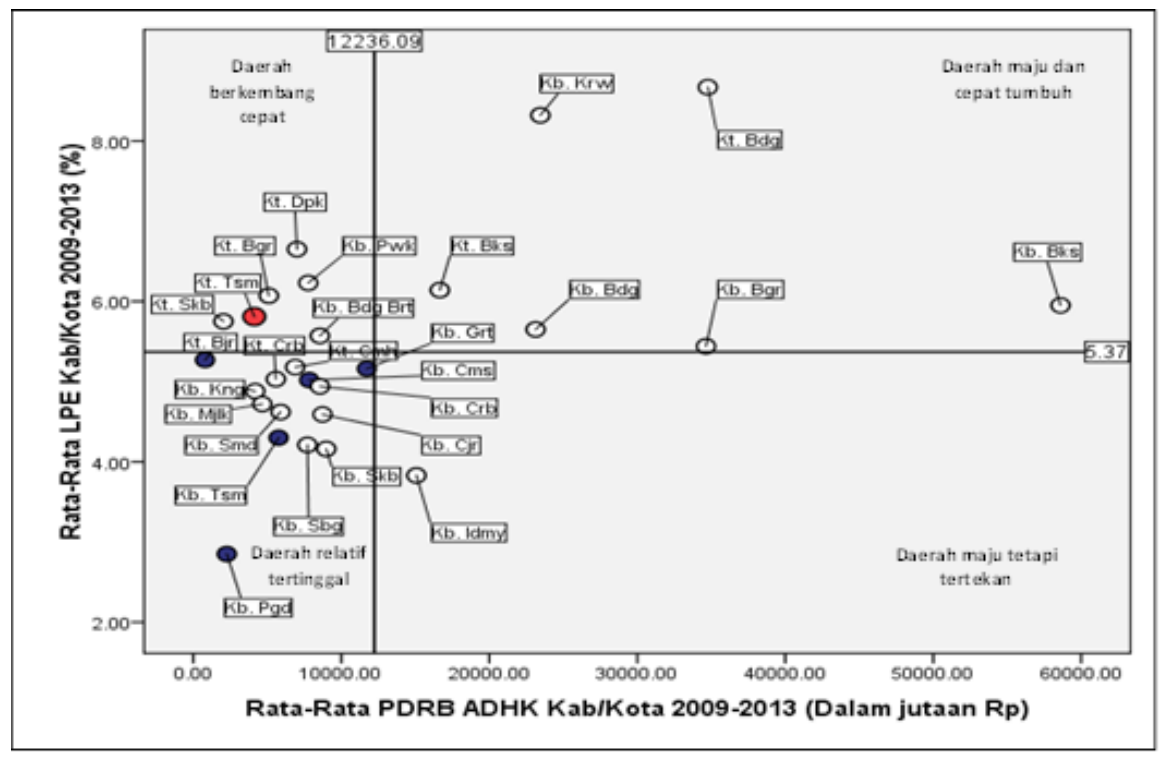

Gambar 1. Tipologi Klassen Kabupaten/Kota se-Provinsi Jawa Barat dan Posisi Kota Tasikmalaya dan Wilayah Hinterland (meliputi Kabupaten Tasikmalaya, Kabupaten Garut, Kabupaten Ciamis, Kabupaten Pangandaran, dan Kota Banjar)

Sumber: data diolah dari BPS Kota: Tasikmalaya dan Banjar (2009-2014), Kabupaten: Tasikmalaya, Garut, Ciamis, dan Kabupaten Pangandaran (2009-2014), BPS Pusat (2009-2013), dan BPS Jawa Barat (2013).

Keterangan:

Kb. Bgr : Kab. Bogor

Kb. Skb : Kab. Sukabumi

Kb. Cjr : Kab. Cianjur

Kb. Bdg : Kab. Bandung

Kb. Grt : Kab.Garut

Kb. Tsm : Kab. Tasikmalaya

Kb. Cms : Kab. Ciamis

Kb. Kng : Kab. Kuningan

Kb. Crb : Kab. Cirebon
Kb. Mjlk : Kab. Majalengka Kb. Smd : Kab. Sumedang

Kb. Idmy : Kab. Indramayu

Kb. Sbg : Kab. Subang

Kb. Pwk : Kab. Purwakarta

Kb. Krw : Kab. Kerawang

Kb. Bks : Kab. Bekasi

Kb. Bdg Brt : Kab.Bandung Barat

Kb. Pgd : Kab. Pangandaran
Kt. Bgr : Kota Bogor

Kt. Skb : Kota Sukabumi

Kt. Bdg : Kota Bandung

Kt. Crb : Kota Cirebon

Kt. Bks : Kota Bekasi

Kt. Dpk : Kota Depok

Kt. Cmh : Kota Cimahi

Kt. Tsm : Kota Tasikmalaya

Kt. Bjr : Kota Banjar 
6 kabupaten/kota, yaitu Kabupaten Kerawang, Kota Bandung dan Bekasi, Kabupaten Bandung, Bogor, dan Kabupaten Bekasi. Klasifikasi daerah berkembang cepat terdapat 6 kabupaten/kota, yaitu Kota Depok, Kabupaten Purwakarta, Kota Bogor, Kota Tasikmalaya, Kota Sukabumi, dan Kabupaten Bandung Barat. Klasifikasi daerah maju tapi tertekan terdapat 1 daerah, yaitu Kabupaten Indramayu. Klasifikasi daerah relatif tertinggal terdapat 14 kabupaten/kota, yaitu Kota Banjar, Kota Cimahi, Kabupaten Garut, Kabupaten Ciamis, Kota Cirebon, Kabupaten Kuningan, Kabupaten Cirebon, Kabupaten Majalengka, Kabupaten Sumedang, Kabupaten Cianjur, Kabupaten Tasikmalaya, Kabupaten Subang, Kabupaten Sukabumi, dan Kabupaten Pangandaran.

Berdasarkan analisis tipologi Klassen kabupaten/ kota se-Provinsi Jawa Barat tahun 2009-2013 (Gambar 1), menunjukkan Kota Tasikmalaya masuk dalam klasifikasi daerah berkembang cepat, wilayah hinterland-nya (Kabupaten Tasikmalaya, Kabupaten Garut, Kabupaten Ciamis, Kota Banjar, dan Kabupaten Pangandaran) masuk dalam klasifikasi daerah relatif tertinggal. Posisi Kota Tasikmalaya sebagai daerah berkembang cepat tersebut didukung oleh ratarata pertumbuhan ekonomi yang cukup tinggi, yaitu 5,81 persen, lebih tinggi dibandingkan rata-rata pertumbuhan ekonomi Kabupaten Tasikmalaya 4,30 persen, Kabupaten Garut 5,16 persen, Kabupaten Ciamis 5,02 persen, Kota Banjar 5,27 persen, dan Kabupaten Pangandaran 2,85 persen. Sebaliknya rata-rata PDRB ADHK tahun 2000 Kota Tasikmalaya relatif kecil, yaitu Rp4.120,12 miliar jika dibandingkan Kabupaten Tasikmalaya Rp5.764,33 miliar Kabupaten Garut Rp11.721,43 miliar dan Kabupaten Ciamis Rp7.823,24 miliar. Namun apabila dibandingkan dengan Kota Banjar Rp791,88 miliar dan Kabupaten Pangandaran Rp2.257,18 miliar rata-rata PDRB ADHK 2000 Kota Tasikmalaya lebih besar.
Hasil analisis tipologi Klassen pada 27 kabupaten/ kota se-Provinsi Jawa Barat menunjukkan bahwa pertumbuhan ekonomi maupun pendapatan per kapita/PDRB ADHK Kota Tasikmalaya dibandingkan dengan 27 kabupaten/kota se-Provinsi Jawa Barat berada pada kuadran II (daerah berkembang cepat). Apabila dibandingkan dengan kab/kota se-Priangan Timur, pertumbuhan ekonomi maupun pendapatan per kapita/PDRB ADHK Kota Tasikmalaya lebih tinggi dibandingkan dengan Kabupaten Tasikmalaya, Kabupaten Garut, Kabupaten Ciamis, Kota Banjar, dan Kabupaten Pangandaran. Pertumbuhan ekonomi dan pendapatan per kapita maupun PDRB ADHK Kota Tasikmalaya yang besar akan memberikan dampak terjadinya migrasi penduduk dari daerah-daerah sekitarnya. Penelitian Pekkala (2003) membuktikan bahwa terjadinya migrasi salah satunya disebabkan oleh upah yang lebih tinggi dan prospek pekerjaan yang lebih baik di daerah perkotaan. Pendapatan dan pekerjaan memikat orang ke pusat pertumbuhan disebabkan utilitas yang dirasakan lebih besar di pusat-pusat pertumbuhan.

\section{Analisis Indeks Diversitas Entropy}

Hasil analisis IDE perkembangan sektor-sektor PDRB Kota Tasikmalaya dan wilayah hinterland (Kabupaten Tasikmalaya, Kabupaten Garut, Kabupaten Ciamis, Kabupaten Pangandaran, dan Kota Banjar) periode tahun 2009-2013 dapat dilihat pada Tabel 6.

Dari Tabel 6, berdasarkan data PDRB ADHK tahun 2000, pada periode tahun 2009-2013 menunjukkan bahwa rata-rata indeks entropi Kota Tasikmalaya lebih tinggi $(0,85)$ dibandingkan dengan wilayah sekitarnya (hinterland), yaitu Kabupaten Tasikmalaya $(0,71)$, Kabupaten Garut $(0,67)$, Kabupaten Ciamis $(0,81)$, Kota Banjar (0,82), dan Kabupaten Pangandaran $(0,74)$. Selain itu, berdasarkan hasil IDE menunjukkan

Tabel 6. Nilai Indeks Diversitas Entropi (IDE) Kota Tasikmalaya dan Wilayah Sekitarnya pada Tahun 2009-2013

\begin{tabular}{|c|c|c|c|c|c|c|c|}
\hline \multirow{2}{*}{ No. } & \multirow{2}{*}{$\begin{array}{c}\text { Kab/kota } \\
\text { Se-Priangan Timur }\end{array}$} & \multicolumn{5}{|c|}{ Tahun } & \multirow{2}{*}{$\begin{array}{l}\text { Rata- } \\
\text { rata }\end{array}$} \\
\hline & & 2009 & 2010 & 2011 & 2012 & 2013 & \\
\hline 1. & Kota Tasikmalaya & 0,86 & 0,85 & 0,85 & 0,85 & 0,84 & 0,85 \\
\hline 2. & Kabupaten Tasikmalaya & 0,70 & 0,70 & 0,70 & 0,71 & 0,72 & 0,71 \\
\hline 3. & Kabupaten Garut & 0,67 & 0,68 & 0,66 & 0,68 & 0,68 & 0,67 \\
\hline 4. & Kabupaten Ciamis & 0,81 & 0,81 & 0,81 & 0,81 & 0,81 & 0,81 \\
\hline 5. & Kota Banjar & 0,82 & 0,82 & 0,82 & 0,82 & 0,82 & 0,82 \\
\hline 6. & Kabupaten Pangandaran & - & - & 0,75 & 0,72 & 0,76 & 0,74 \\
\hline
\end{tabular}

Sumber: Hasil analisis IDE, data diolah dari BPS Kota Tasikmalaya, Kabupaten Tasikmalaya, Kabupaten Garut, Kabupaten Ciamis, Kota Banjar, dan Kabupaten Pangandaran (2009-2014). 
bahwa sektor-sektor ekonomi Kota Tasikmalaya lebih berkembang. Beberapa sektor tersebut, yaitu industri pengolahan; listrik, gas dan air bersih; bangunan; perdagangan, hotel dan restoran; pengangkutan dan komunikasi, serta keuangan, persewaan, dan jasa keuangan, memberikan sumbangan yang besar dalam pembentukan PDRB Kota Tasikmalaya.

Hasil analisis IDE menunjukkan pula bahwa aktivitas ekonomi Kota Tasikmalaya lebih beragam, lebih berkembang, dan maju. Sama halnya dengan hasil penelitian Pede (2013) pada kabupatenkabupaten di Amerika Serikat selama periode tahun 1990-2007, menemukan bahwa keragaman ekonomi memperkuat dan memberikan dampak positif terhadap pertumbuhan ekonomi daerah. Aktivitas ekonomi Kota Tasikmalaya yang lebih beragam mendorong perkembangan perekonomian wilayah Kota Tasikmalaya lebih maju dibandingkan dengan Kabupaten Tasikmalaya, Kabupaten Garut, Kabupaten Ciamis, Kota Banjar, dan Kabupaten Pangandaran. Aktivitas ekonomi yang beragam menjadi daya tarik masyarakat di wilayah sekitarnya. Perekonomian wilayah Kota Tasikmalaya yang lebih maju dan berkembang memberikan spread effect bagi wilayah sekitarnya.

\section{Analisis Location Quotient (LQ)}

Hasil analisis LQ sektor-sektor dalam perekonomian wilayah Kota Tasikmalaya dan wilayah hinterland-nya (Kabupaten Tasikmalaya, Garut, Ciamis, Pangandaran, dan Kota Banjar) terhadap sektor-sektor perekonomian Provinsi Jawa Barat dapat dilihat pada Tabel 7.

Tabel 7 menunjukkan hasil analisis $L Q$, pada (a) Kota Tasikmalaya, hasil analisis LQ tahun 2009 dan 2013 menunjukkan terdapat 5 sektor yang memiliki nilai $L Q>1$, yaitu sektor bangunan $(3,12)$, sektor keuangan, persewaan, dan jasa $(3,08)$, sektor jasajasa $(1,75)$, sektor pengangkutan dan komunikasi $(1,66)$ dan sektor perdagangan, hotel, dan restoran $(1,44)$, di mana sektor-sektor ini dikategorikan sektor basis. Sedang 4 sektor memiliki rata-rata nilai LQ < 1 , yaitu sektor listrik dan air bersih $(0,73)$, pertanian $(0,60)$, industri pengolahan $(0,40)$ dan pertambangan dan penggalian $(0,00)$ dikategorikan sebagai sektor nonbasis, (b) Kabupaten Tasikmalaya, hasil analisis LQ tahun 2009 dan 2013 menunjukkan terdapat 4 sektor yang memiliki nilai $L Q>1$, yaitu sektor pertanian $(3,47)$, diikuti sektor jasa-jasa $(2,19)$, sektor keuangan, persewaan, dan jasa $(1,13)$, sektor perdagangan, hotel, dan restoran $(1,05)$, sektorsektor ini dikategorikan sektor basis. Sedang 5 sektor memiliki rata-rata nilai $L Q<1$, yaitu sektor pengangkutan dan komunikasi $(0,96)$, listrik dan air bersih $(0,45)$, bangunan $(0,19)$, industri pengolahan
$(0,18)$, dan sektor pertambangan serta penggalian $(0,11)$, sektor tersebut dikategorikan sebagai nonbasis, (c) Kabupaten Garut, hasil analisis LQ tahun 2009 dan 2013 menunjukkan terdapat 4 sektor yang memiliki nilai $L Q>1$, yaitu sektor pertanian $(3,65)$, diikuti sektor jasa-jasa $(1,42)$, perdagangan, hotel, dan restoran $(1,27)$, dan sektor keuangan, persewaan, serta jasa $(1,09)$, sektor-sektor ini dikategorikan sektor basis. Sedang 5 sektor memiliki rata-rata nilai $L Q<1$, yaitu sektor bangunan $(0,77)$, pengangkutan dan komunikasi $(0,58)$, listrik dan air bersih $(0,25)$, industri pengolahan $(0,17)$, dan sektor pertambangan serta penggalian $(0,06)$ merupakan sektor nonbasis, (d) Kabupaten Ciamis, hasil analisis LQ tahun 2009 dan 2013 menunjukkan terdapat 6 sektor yang memiliki nilai $L Q>1$, yaitu sektor jasa-jasa $(2,41)$, diikuti sektor pertanian $(2,30)$, pengangkutan dan komunikasi $(1,67)$, keuangan, persewaan, dan jasa (1,59), bangunan $(1,40)$, dan sektor perdagangan, hotel, serta restoran $(1,23)$, sektorsektor ini dikategorikan sektor basis. Sedang 3 sektor memiliki rata-rata nilai $L Q<1$, yaitu sektor listrik dan air bersih $(0,30)$, industri pengolahan $(0,18)$, dan pertambangan serta penggalian $(0,16)$ merupakan sektor nonbasis, (e) Kota Banjar, hasil analisis LQ tahun 2009 dan 2013 menunjukkan terdapat 6 sektor yang memiliki nilai LQ $>1$, yaitu sektor jasa-jasa $(2,18)$, diikuti sektor keuangan, persewaan, dan jasa $(1,89)$, perdagangan, hotel, dan restoran $(1,56)$, pertanian $(1,49)$, bangunan $(1,47)$, dan pengangkutan serta komunikasi $(1,46)$, sektor-sektor ini dikategorikan sektor basis. Sedangkan 3 sektor memiliki rata-rata nilai $L Q<1$, yaitu listrik dan air bersih $(0,45)$, industri pengolahan $(0,28)$, dan pertambangan \& penggalian $(0,13)$ merupakan sektor nonbasis; (f) Kabupaten Pangandaran, hasil analisis LQ tahun 2009 dan 2013 menunjukkan terdapat 5 sektor yang memiliki nilai $\mathrm{LQ}>1$, yaitu sektor pertanian $(2,80)$, diikuti sektor jasa-jasa $(2,43)$, perdagangan, hotel, dan restoran $(1,44)$, keuangan, persewaan, dan jasa $(1,28)$, serta bangunan $(1,15)$, sektor-sektor ini dikategorikan sektor basis. Sedang 4 sektor memiliki rata-rata nilai $\mathrm{LQ}<1$, yaitu sektor pertambangan dan penggalian $(0,33)$, listrik dan air bersih $(0,32)$, pengangkutan dan komunikasi $(0,32)$, serta sektor industri pengolahan $(0,28)$ kategori sektor nonbasis.

Sektor-sektor yang memiliki rata-rata nilai LQ > 1 diasumsikan sektor mampu memenuhi kebutuhan lokal serta memiliki kelebihan produk yang bisa dikembangkan dan diekspor, serta memberikan sumbangan yang besar terhadap PDRB kabupaten/ kota dibandingkan sumbangan sektor yang sama terhadap PDRB provinsi. Jika dilihat besaran rata-rata LQ sektor-sektor ekonomi, dalam analisis tahun 2009 dan tahun 2013, menunjukkan rata-rata LQ Kota 


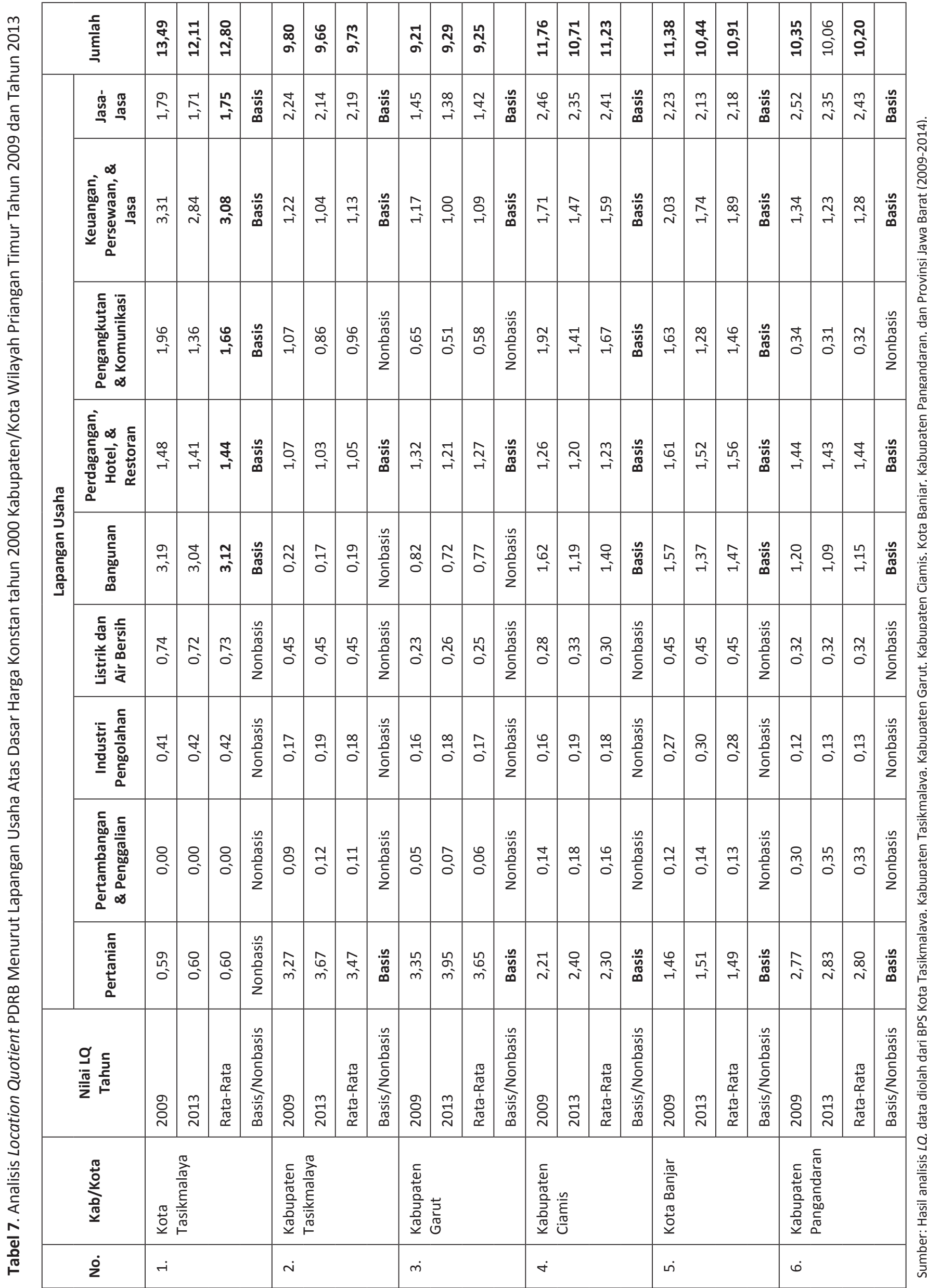


Tasikmalaya lebih besar, yaitu 12,80 dibandingkan daerah sekitarnya, yaitu Kabupaten Tasikmalaya 9,73, Kabupaten Garut 9,25, Kabupaten Ciamis 11,23, Kota Banjar 10,91, dan Kabupaten Pangandaran 10,20.

Hasil analisis LQ menunjukkan bahwa sektorsektor perekonomian di Kota Tasikmalaya, yaitu sektor bangunan, sektor perdagangan, hotel, dan restoran, sektor pengangkutan dan komunikasi, sektor keuangan, persewaan, jasa keuangan, dan sektor jasa-jasa memiliki nilai $L Q>1$. Artinya sektor ini merupakan sektor basis atau unggulan dan sebagai penggerak perekonomian bagi Kota Tasikmalaya. Suatu kota yang sedang bertumbuh dan berkembang biasanya akan diikuti dengan aktivitas pembangunan yang tinggi. Di satu sisi akan memacu terjadinya transaksi ekonomi, di sisi lain sebagai kota juga akan menarik masyarakat dari daerah sekitarnya, sehingga akan mendorong dan menggerakkan sektor-sektor ekonomi lainnya. Melihat banyaknya sektor basis/ unggulan berdasarkan perhitungan rata-rata $L Q$ Kota Tasikmalaya yang lebih besar dibandingkan daerah sekitarnya, maka posisi Kota Tasikmalaya sebagai pusat pertumbuhan wilayah Priangan Timur cukup tepat karena mempunyai keunggulan lokasi dibandingkan daerah sekitarnya.

\section{SIMPULAN DAN SARAN}

\section{A. Simpulan}

Hasil penelitian menunjukkan struktur perekonomian wilayah Kota Tasikmalaya lebih maju dan berkembang. Hal ini terlihat dari hasil analisis tipologi Klassen dan IDE pada masingmasing kabupaten/kota se-Provinsi Jawa Barat. Posisi Kota Tasikmalaya masuk klasifikasi daerah berkembang cepat dibandingkan wilayah hinterlandnya (Kabupaten Tasikmalaya, Kabupaten Garut, Kabupaten Ciamis, Kota Banjar, dan Kabupaten Pangandaran) yang diklasifikasikan sebagai daerah relatif tertinggal. Hasil analisis IDE menunjukkan jika rata-rata indeks entropi Kota Tasikmalaya lebih tinggi $(0,85)$ dibandingkan Kabupaten Tasikmalaya $(0,71)$, Kabupaten Garut $(0,67)$, Kabupaten Ciamis $(0,81)$, Kota Banjar $(0,82)$, dan Kabupaten Pangandaran $(0,74)$. Indeks entropi yang tinggi menunjukkan perekonomian wilayah Kota Tasikmalaya lebih maju dan berkembang.

Hasil penelitian juga menunjukkan bahwa perekonomian wilayah Kota Tasikmalaya lebih unggul, di mana rata-rata LQ Kota Tasikmalaya $(12,80)$ lebih besar dibandingkan LQ wilayah hinterland-nya, yaitu Kabupaten Tasikmalaya $(9,73)$, Kabupaten Garut $(9,25)$, Kabupaten Ciamis $(11,23)$, Kota Banjar $(10,91)$, dan Kabupaten Pangandaran $(10,20)$. (a) sektor bangunan, (b) sektor perdagangan, hotel, dan restoran, (c) pengangkutan dan komunikasi, (d) keuangan, persewaan dan jasa keuangan, serta (e) sektor jasa-jasa.

\section{B. Saran}

Saran yang dapat direkomendasikan dari penelitian ini adalah (1) kebijakan desentralisasi dan otonomi daerah dengan implikasi pemekaran wilayah tahun 2001 telah mendorong perkembangan ekonomi wilayah Kota Tasikmalaya lebih maju dan berkembang dibandingkan daerah sekitarnya (hinterland). Otonomi daerah (pemekaran wilayah) memberikan manfaat terhadap daerah pemekaran itu sendiri. Agar Kota Tasikmalaya lebih maju dan berkembang, perlu ditetapkan kebijakan pembangunan yang diprioritaskan pada sektor basis atau unggulan, yaitu bangunan; perdagangan, hotel, dan restoran; pengangkutan dan komunikasi; keuangan, persewaan, dan jasa keuangan, serta sektor jasa-jasa dengan tetap memerhatikan sektor lainnya secara proporsional sesuai potensi dan peluang pengembangannya dan (2) sebagai pusat pertumbuhan wilayah di Priangan Timur, Pemerintahan Kota Tasikmalaya perlu meningkatkan kualitas jasa pelayanan, seperti jasa pelayanan perdagangan, pendidikan, serta hiburan dan rekreasi, yang biasanya kurang dimiliki daerah sekitarnya. Hal ini akan meningkatkan daya tarik bagi daerah sekitarnya serta menjadi sumber-sumber pendapatan ekonomi dari luar Kota Tasikmalaya.

Upaya untuk mendorong perkembangan perekonomian wilayah, selain meningkatkan sektor basis atau unggulan sebagai penggerak perekonomian wilayah, Pemerintah Kota Tasikmalaya perlu mengembangkan kebijakan baru yang lebih mendorong, memfasilitasi, dan memberikan ruang bagi tumbuhnya investasi, yaitu melalui insentif pajak dan kemudahan berinvestasi. Hal ini dapat memberikan dampak bagi pengembangan perekonomian wilayah dengan tetap mendorong dan mengembangkan industri-industri serta sektor pengolahan lainnya yang telah ada. Selain itu, dalam upaya meningkatkan keterkaitan Kota Tasikmalaya dengan wilayah sekitarnya, perlu diupayakan untuk membuat konsep perjanjian kerja sama kabupaten/ kota se-Priangan Timur. 


\section{DAFTAR PUSTAKA}

\section{Buku}

Adisasmita, R. (2008). Pengembangan wilayah: Konsep dan teori. Yogyakarta: Graha IImu.

Badan Pusat Statistik Kabupaten Ciamis. (2013 dan 2014). Ciamis dalam angka 2014. Ciamis: BPS Kabupaten Ciamis.

Badan Pusat Statistik Kabupaten Garut. (2013 dan 2014). Garut dalam angka 2014. Garut: BPS Kabupaten Garut.

Badan Pusat Statistik Kabupaten Pangandaran. (2013 dan 2014). Pangandaran dalam angka 2014. Pangandaran: BPS Kabupaten Pangandaran.

Badan Pusat Statistik Kabupaten Tasikmalaya. (2013 dan 2014). Tasikmalaya dalam angka 2014. Tasikmalaya: BPS Kabupaten Tasikmalaya.

Badan Pusat Statistik Kota Tasikmalaya. (2013 dan 2014). Kota Tasikmalaya dalam angka 2014. Tasikmalaya: BPS Kota Tasikmalaya.

Badan Pusat Statistik. (2013 dan 2014). Jawa Barat dalam angka 2014. Bandung: BPS Provinsi Jawa Barat.

Bappenas dan United Nations Development Programme (UNDP). (2008). Studi evaluasi dampak pemekaran daerah 2001-2007. Jakarta: BRIDGE (Building and Reinventing Decentralised Governance).

Budiharsono, S. (2001). Teknik analisis pembangunan wilayah pesisir dan lautan. Jakarta: PT Pradnya Paramita.

Higgins, B. and Salvoie, D. J. (2005). Regional development theories and their application. New Brunswick, New Jersey: Transaction Publicers.

Kuncoro, M. (2013). Mudah memahami dan menganalisis indikator ekonomi. Yogyakarta: UPP STIM YKPN.

Kuncoro, M. (2012). Perencanaan daerah: Bagaimana membangun ekonomi lokal, kota, dan kawasan. Jakarta: Salemba Empat.

Kuncoro, M. (2004). Otonomi dan pembangunan daerah: Reformasi, perencanaan, strategi dan peluang. Jakarta: Erlangga.

Kuncoro, M. (2002). Analisis spasial dan regional: Studi aglomerasi dan kluster industri Indonesia. Yogyakarta: UPP AMP YKPN.
Muta'ali, L. (2011). Kapita selekta pengembangan wilayah. Yogyakarta: Fakultas Geogragi UGM.

Nazara, S. (1994). Pertumbuhan ekonomi Indonesia: Suatu aplikasi fungsi produksi agregat Indonesia 1985-1991. Prisma No. 8. Jakarta: PT. Pustaka PL3ES Indonesia.

Nugroho, K. S. (2011). Pemekaran daerah, dapatkah menjadi model pemerataan pembangunan (Kasus pemekaran di Propinsi Banten). Proceeding Simposium Nasional Otonomi Daerah: Best practices dalam penyelenggaraan otonomi daerah. Serang Banten: Fisip Untirta dan LAN Fisip Untirta.

Nurzaman, S. S. (2012). Perencanaan wilayah dalam konteks Indonesia. Bandung: Institut Teknologi Bandung.

Pribadi, O. D., Panuju, D. R., Rustiadi, E., dan Emma, A. P. (tanpa tahun). Permodelan perencanaan pengembangan wilayah: Konsep, metode, aplikasi dan teknik komputasi (tidak dipublikasikan).

Ratnawati, T. (2009). Pemekaran daerah: Politik lokal dan beberapa isu terseleksi. Jakarta: Pustaka Pelajar.

Riyadi dan Bratakusumah, D. S. (2004). Perencanaan pembangunan daerah: Strategi menggali potensi dalam mewujudkan otonomi daerah. Jakarta: PT Gramedia Pustaka Utama.

Rustiadi, E., Saefulhakim, S., dan Panuju, D. R. (2009). Perencanaan dan pengembangan wilayah. Jakarta: Crespent Press dan YOI.

Setiono, D. N. S. (2011). Ekonomi pengembangan wilayah: Teori dan aplikasi. Jakarta: Fakultas Ekonomi Universitas Indonesia.

Sjafrizal. (2008). Ekonomi regional: Teori dan aplikasi. Padang: Baduose Media.

Sjafrizal. (1997). Pertumbuhan ekonomi dan ketimpangan regional wilayah Indonesia bagian barat. Prisma No. 3. Jakarta: PT. Pustaka PL3ES Indonesia.

Tarigan, R. (2005). Ekonomi regional: Teori dan aplikasi. Jakarta: PT Bumi Aksara.

\section{Jurnal dan Working Paper}

Agustino, L. dan Yussof, M. A. (2008). Proliferasi dan etno nasionalisme daripada pemberdayaan dalam pemekaran daerah di Indonesia. Jurnal Ilmu Administrasi dan Organisasi, 15(3), 196201. 
Booth, A. (2011). Splitting, splitting and splitting again: A brief history of the development of regional government in Indonesia since independence. Bijdragen tot de Taal-Land-en Volkenkunde, 167(1), 31-59.

Butt, S. (2010). Regional autonomy and legal disorder: The proliferation of local laws in Indonesia. Singapore Journal of Legal Studies, 1-21.

Cheema, G. S., and Rondinelli, D. A. (2007). Decentralizing governance: Emerging concepts and practices. Dalam From Government Decentralization to Decentralized Governance. Washington: Brooking Institution Press.

Dawkins, C. J. (2003). Regional development theory: Conceptual foundations, classic works, and recent developments. Journal of Planning Literature, 18(2), 131-172.

Juanda, B. (2007). Manfaat dan biaya pemekaran daerah serta implikasinya terhadap APBN. Jurnal Ekonomi, Vol. 25, 36-51.

Monsted, M. (1974): François Perroux's theory of growth pole and development pole: A critique. Antipode, 6(2), 106-113.

Pamungkas, C. (2007). Pemekaran wilayah, otonomi daerah dan desentralisasi politik di Indonesia. Jakarta USAID-DRSP-Percik-LIPI.

Parr, J. B. (1999). Growth pole strategies in regional economic planning: A retrospective view. Part 1: Origins and advocacy. Urban Studies, 36(7), 1.195-1.215.

Pede, O.V. (2013). Diversity and regional economic growth: Evidence from US Counties. Journal of Economic Development, 38(3), 111-127.

Pekkala, S. (2003). What draws people to urban growth centers: Jobs vs. pay?. Government Institute for Economic Research.
Ratnawati, T. (2010). Satu dasa warsa pemekaran daerah Era reformasi: Kegagalan otonomi daerah. Jurnal Ilmu Politik, No. 21, 122-145.

Sutikno dan Maryunani. (2007). Analisis daya saing kecamatan sebagai pusat pertumbuhan Satuan Wilayah Pengembangan (SWK) Kabupaten Malang.Journal of Indonesia Applied Economics, 1(1), 1-17.

Tryatmoko, M. W. (2010). Pemekaran daerah dan persoalan governability lokal di Indonesia. Jurnal Penelitian Politik, 7(1), 42-43.

Tesis

Agusniar, A. (2006). Analisis dampak pemekaran wilayah terhadap perekonomian wilayah dan kesejahteraan masyarakat (Studi kasus di Kabupaten Aceh Singkil Propinsi Nanggroe Aceh Darussalam). (Tidak dipublikasikan). Tesis, Sekolah Pascasarjana IPB, Bogor.

\section{Dokumen}

Kemendagri, (2013). Daerah otonom baru di Indonesia per provinsi tahun 1999-2013. KPPOD, Jakarta.

\section{Peraturan Perundang-undangan}

Peraturan Pemerintah No. 78 Tahun 2007 tentang Tata Cara Pembentukan, Penghapusan, dan Penggabungan Daerah.

Undang-Undang No. 22 Tahun 1999 tentang Pemerintahan Daerah.

Undang-Undang No. 32 Tahun 1999 tentang Pemerintahan Daerah. 